\title{
THE QUALITY OF SEAHORSE JUVENILES Hippocampus barbouri AFTER MODIFYING NATURAL FEED Artemia NAUPLII TO Phronima sp.
}

\author{
Fakhirah Ahmad ${ }^{1}$, Syafiuddin $^{2}$, Haryati $^{3}$ \\ Submitted: August 20, 2019, Accepted: October 8, 2019
}

\author{
${ }^{1,3}$ Department of Fisheries, Faculty of Marine Science and Fisheries, University of Hasanuddin \\ ${ }^{2}$ Department of Marine Science, Faculty of Marine Science and Fisheries, University of Hasanuddin \\ Jl. Perintis Kemerdekaan Km.10, Makassar, Indonesia, 90245 \\ Corresponding Author: \\ Syafiuddin \\ Email: afi_makassar@yahoo.com
}

\begin{abstract}
This study aims to determine the substitution rate of Artemia naupli to Phronima sp., which produces high-quality seahorses $\mathrm{H}$. Barbouri juveniles This research was carried out using CRD (Completed Randomized Design) with five treatments and three replications. The treatments were natural feeding with different levels of substitution, (A) $100 \%$ Artemia nauplii, (B) 75\% Artemia nauplii $+25 \%$ Phronima sp. (C) 50\% Artemia nauplii $+50 \%$ Phronima, (D) $25 \%$ Artemia nauplii $+75 \%$ Phronima sp. and (E) 100\% Phronima sp. Data were analyzed with Analysis of Variance and $\mathrm{W}$-Tuckey test to determine the significant difference between the treatments. The parameters of the study included the analysis of feed quality (proximate and amino acid analysis) and survival. Results of the ANOVA indicated that the substitution of Artemia nauplii to Phronima sp. had a significant effect $(\mathrm{P}<0.05)$ on survival rate. Based on the result of the proximate analysis of Phronima, the protein and fat content is insufficient for juvenile requirements, which only ranged from $37,12 \%$ and $3,82 \%$. The results of the amino acid analysis of Phronima, the total of essential amino acids are deficient in juvenile requirements. The treatments of $\mathrm{C}$ and $\mathrm{D}$ produces the highest survival value of $96,67 \%$. While in E treatment produce the lowest survival value of $63,33 \%$. Based on the juvenile quality analysis, it can be concluded that the use of Phronima as an alternative feed for seahorse juveniles $\mathrm{H}$. barbouri can be given at a substitution rate of up to $75 \%$.
\end{abstract}

Keywords: Artemia naupli, Hippocampus barbouri, Juvenile, Phronima sp., Sea horse

\section{INTRODUCTION}

Seahorses are fish species that have high economic value and have been widely traded as ornamental fish, souvenirs, and dried as a raw material for traditional Chinese medicines (Rosa et al., 2011). At present, the seahorse population has decreased due not only to habitat loss but also due to overexploitation (Koldewey \& Smith, 2010). Cultivation is the right answer to avoid overfishing and optimal use of resources. Some countries are known to have carried out seaweed hatchery activities, among others; the Philippines, Vietnam, China, India, and Australia. Whereas in Indonesia, the development of seaweed hatchery activities in both the mass and the backyard scale has been carried out in Lampung Sea Cultivation Center and also in South Sulawesi on the island of Sabutung of Pangkep Regency and Badi Island, Mattiro Deceng Village of Pangkep Regency.

Sea horses are passive predators, animals that wait for feed to pass and attack their prey by sucking using a long snout. So far, the type of natural feed given by seahorse juvenile is Artemia salina naupli, because, in addition to being natural in the culture process, it is also available commercially (Payne \&Rippingale, 2000). However, Artemia salina is one of the natural feed with high selling prices in the market. The quality requirements for feed use are continuity of availability, nutritional content, affordable prices, and not as a carrier of the disease (Handajani \& Widodo, 2010). Therefore there's the need for alternative feed that can replace Artemia salina.

Santoso (2014) found the main feed derived from the Amphipoda order, complementary originating from the Mysida and Calanoid orders and supplementary derived from Harpatocoida, Isopoda and Euphasiacea order. Phronima sp. is a type of micro crustacea from the Amphipoda order which found naturally live in the waters of Wiringtasi and Tasiwalie Villages of Pinrang Regency, South Sulawesi. Phronima has enormous potential as an alternative feed to replace Artemia, which is commonly used as feed on fish and shrimp seeds (Fattah et al., 2014). The existence of Phronima sp. in the ponds of tiger shrimp pond maintenance, has been known to have succeeded in increasing the survival value by $70 \%$ compared with no Phronima maintenance,. The survival was only 10\% (Fattah \& Senong, 2008).

Based on the description above, information on Phronima sp. being as feed has never been done before for the $\mathrm{H}$. barbouri's seahorse juvenile rearing which is expected to be able to substitute 
Artemia naupli which is still imported from the outside, so the need for research on the use of Phronima sp. as a sea horse juveniles feed. This study aimed to determine the level of substitution of Phronima in replacing Artemia naupli as an alternative feed for the rearing of $\mathrm{H}$. barbouri juveniles so that it will produce the best survival.

\section{MATERIALS AND METHODS}

\section{Test animals}

The test animals used were 7-day-old $H$. barbouri seahorse juveniles with a body length of $1.5 \mathrm{~cm}$. Juveniles were obtained from the spawning natural in the backyard. Seahorses broodstock obtained from Tanakeke waters, Takalar Regency, South Sulawesi.

\section{Experimental container}

Juvenile sea horses were maintained using 5-liter plastic containers equipped with buoys on each side. The container for juvenile sea horse designed by using a recirculation and water bath system equipped with filters (Figure 1). The purpose of this design was that the quality of water in the juvenile media remains stable and easy to control.

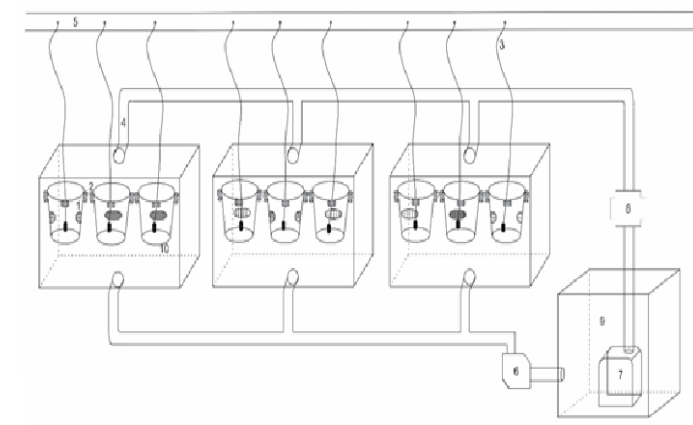

Figure 1. Design of a media container for $H$. barbouri juveniles

Notes: (1) juveniles media containers, (2) buoys, (3) aeration hoses, (4) inlet pipes, (5) oxygen distribution pipes, (6) biological filters, (7) pumps, (8) filter cartridges , (9) filtration containers and (10) filter.

\section{Feed preparation}

Artemia obtained from hatchery_while Phronima sp. obtained from Tasiwalie Village, Pinrang then cultured in a 1-ton tub. Before the experiments started, the juveniles fasted a day, on the sixth day of rearing, which aimed to empty the contents of the previous feed of the juveniles. The treatments started on the seventh day $( \pm 0.65 \mathrm{~mm})$. This was due to the size of Phronima $( \pm 0.45 \mathrm{~mm})$, which was higher than the size of the juvenile mouth opening $( \pm 0.4 \mathrm{~mm})$. While the size of Artemia naupli was $\pm 0.3 \mathrm{~mm}$. On the first until the fifth day of rearing the juveniles were fed with the newly hatched Artemia naupli.

\section{Broodstock of Sea horses}

The broodstock spawned in the backyard was obtained from the catches of fishermen in the Tanakeke Islands, Takalar Regency, with lengths for male and $\pm 14 \mathrm{~cm}$ female. The broodstock was reared in a 7001 tank. During rearing; the broodstock was given Phronima sp., the frequency of feeding twice as satiation, in the morning at 08.00 and in the afternoon at 16.00.

\section{Juveniles rearing}

Juveniles obtained from spawning then moved into the treatment container. The rearing of juveniles was 21 days with a density of 2 fish / L (Mulyadi, 2004) using containers with a volume of 5 liters of water. During research, water change was carried out as much as $50 \%$ every week and diluting the remaining feces every day on the bottom of the media container.

\section{Experimental design and data analysis}

This study was conducted using a completely randomized design with five treatments and three replications. The treatments were feeding with each different level density. On the first day until the fifth day of rearing was given the newly hatched Artemia naupli. Feeding for each treatment began on the seventh day of the study. (A) $100 \%$ Artemia naupli (as a control), (B) $75 \%$ Artemia naupli, 25\% Phronima sp :; (C) $50 \%$ Artemia naupli, 50\% Phronima sp. (D) $25 \%$ Artemia nauplii, 75\% Phronima sp. and (E) $100 \%$ Phronima sp.

The parameters of the study included testing the quality of feed by conducting proximate and amino acid analysis tests and calculation of survival rate. Data on feed quality testing will be described descriptively while the data from the calculation of survival obtained were analyzed using variance analysis. Data that had a significant effect ( $P$ $<0.05)$ were carried out by the W-Tuckey further test to see the differences in each treatment performed. Moreover, water quality measurements were also carried out during the research.

\section{RESULTS AND DISCUSSION}

\section{Feed quality analysis}

The proximate analysis results in (Table 1) produce the protein content values of treatments A, $\mathrm{B}, \mathrm{C}, \mathrm{D}$ and $\mathrm{E}$ which were $61.47 \%$; $55.38 \%$; $49.30 \% ; 43.21 \%$ and $37.12 \%$. The fat content produced in treatment $\mathrm{A}, \mathrm{B}, \mathrm{C}, \mathrm{D}$, and $\mathrm{E}$ were 
$21.55 \% ; 17.12 \% ; 12.69 \% ; 8.25 \%$ and $3.82 \%$. The value of crude fiber content in each treatment $\mathrm{A}, \mathrm{B}$, $\mathrm{C}, \mathrm{D}$, and $\mathrm{E}$ were $2.79 \% ; 9.36 \% ; 15.94 \% ; 22.51 \%$ and $29.08 \%$. The ash content in treatments A, B, C, D and E were $6.27 \% ; 11.73 \% ; 17.20 \% ; 22.66 \%$ and $28.12 \%$. NFE (Nitrogen Free Extract) or carbohydrates content in each treatment A, B, C, D and $\mathrm{E}$ which were $7.92 \% ; 6.41 \% ; 4.90 \% ; 3.38 \%$ and $1.87 \%$.

The total feed energy produced in all treatment A, $\mathrm{B}, \mathrm{C}, \mathrm{D}$, and $\mathrm{E}$ was lower with increasing percentage substitution of Artemia naupli with Phronima sp. The total value of energy produced in treatments A, B, C, D, and E were $409.5 \mathrm{kcal} / \mathrm{g}$ respectively; $348.52 \mathrm{kcal} / \mathrm{g} ; 287.58 \mathrm{kcal} / \mathrm{g} ; 226.51$ $\mathrm{kcal} / \mathrm{g}$ and $165.53 \mathrm{kcal} / \mathrm{g}$.

Table 1 . The proximate analysis

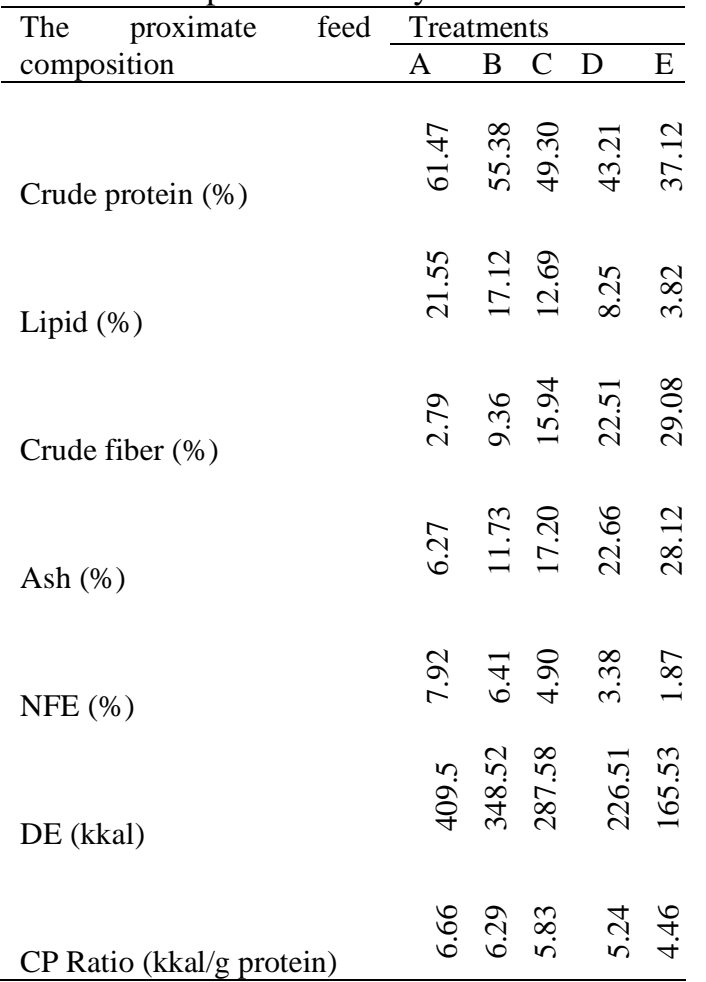

Notes :

$1 . \%$ dry weight;

2. A (100\% Artemia naupli), B $(75 \%$ Artemia $+25 \%$ Phronima naupli), C (50\% Artemia $+50 \%$ Phronima naupli), D (25\% Artemia $+75 \%$ Phronima nauplii) and E (100\% Phronima);

3 . The value of the proximate analysis of treatments A and $\mathrm{E}$ is obtained from the proximate analysis results;

4. The proximate analysis of treatment B, C and D is obtained from the calculation;

5. NFE (Nitrogen Free Extract);

6. DE (Digestible Energy);

7. EP (Comparison of energy with protein);

8. Energy calculation based on NRC (1993) (1g protein $3.5 \mathrm{kcal} / \mathrm{g}, 1 \mathrm{~g}$ fat: $8.1 \mathrm{kcal} / \mathrm{g}, 1 \mathrm{~g}$ carbohydrate: 2.5 $\mathrm{kcal} / \mathrm{g})$.
Table 2. Amino acid composition in natural feed and the body of sea horse juveniles $H$. barbouri (\%) body protein

\begin{tabular}{|c|c|c|c|c|c|}
\hline \multirow[t]{2}{*}{ Amino Acid } & \multicolumn{4}{|c|}{ Feed treatments } & \multirow[t]{2}{*}{$\begin{array}{l}\text { Sea horse } \\
\text { juveniles }\end{array}$} \\
\hline & A B & $\mathrm{C}$ & $\mathrm{D}$ & $E$ & \\
\hline \multicolumn{6}{|c|}{ Essential A. Acid } \\
\hline Histidine & $\stackrel{ \pm}{\dot{0}}$ & $\frac{1}{0}$ & $=$ & $\exists$ & $\stackrel{1}{0}$ \\
\hline Arginine & $\stackrel{a}{\stackrel{0}{0}}$ & $\stackrel{\infty}{\circ}$ & $\stackrel{0}{0}$ & $\stackrel{\circ}{\circ}$ & $\stackrel{\infty}{\stackrel{0}{0}}$ \\
\hline Threonin & ָั ণิ & $\frac{0}{0}$ & $\frac{m}{0}$ & $\stackrel{\circ}{\circ}$ & $\stackrel{9}{0}$ \\
\hline Valine & 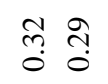 & ָิ & 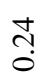 & ָ̦ & $\grave{ָ}$ \\
\hline I-leucine & 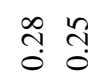 & กิ & กิ & $\frac{1}{0}$ & $\frac{1}{0}$ \\
\hline Leucine & 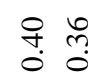 & $\stackrel{m}{0}$ & ֻి & $\grave{\jmath}$ & @ి \\
\hline Lysine & 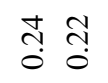 & స઼. & $\frac{9}{0}$ & $\frac{\infty}{0}$ & ֻิ \\
\hline Phenylalanine & $\stackrel{\tilde{c}}{0} \overline{0}$ & กิ & $\stackrel{\infty}{0}$ & $\frac{1}{0}$ & $\grave{\hat{o}}$ \\
\hline Methionine & †े ڤ̊ & ֻ̊? & $\tilde{ก}$ & $\frac{m}{0}$ & $\stackrel{\infty}{\circ}$ \\
\hline Tryptophan & $\stackrel{n}{0} \stackrel{ \pm}{0}$ & $\stackrel{m}{0}$ & $\stackrel{1}{\delta}$ & ō & $\stackrel{0}{0}$ \\
\hline
\end{tabular}

\begin{tabular}{|c|c|c|c|c|c|}
\hline \multicolumn{6}{|c|}{ Non-Essential A. Acid } \\
\hline Aspartic acid & $\stackrel{\overbrace{}}{\tilde{c}}$ & $\begin{array}{ll}\vec{y} & \stackrel{9}{0} \\
\end{array}$ & $\frac{1}{0}$ & $\frac{n}{0}$ & సి \\
\hline Glutamic acid & $\frac{n}{\stackrel{n}{o}}$ & : & "̊? & ก̊? & $\stackrel{\infty}{+}$ \\
\hline Serine & $\vec{\jmath}$ & $\frac{a}{\dot{0}} \stackrel{0}{\overrightarrow{0}}$ & $\stackrel{ \pm}{\dot{0}}$ & $=$ & $\frac{\infty}{0}$ \\
\hline Glycine & $\stackrel{m}{\tilde{c}}$ & $\begin{array}{ll}+ & n \\
m & n \\
0 & 0\end{array}$ & ஸे & $\stackrel{\infty}{\mathfrak{m}_{0}}$ & $\stackrel{\infty}{n}$ \\
\hline Alanin & $\stackrel{\infty}{\infty}$ & 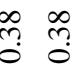 & $\stackrel{\infty}{n}$ & $\stackrel{\infty}{?}$ & $\stackrel{q}{+}$ \\
\hline Proline & $\stackrel{\infty}{\stackrel{\infty}{0}}$ & 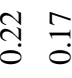 & $\frac{1}{0}$ & 웅 & $\stackrel{\sim}{0}$ \\
\hline Tyrosine & $\stackrel{1}{\infty}$ & $\begin{array}{cc}5 & 0 \\
0 & 0\end{array}$ & $\stackrel{n}{0}$ & $\stackrel{n}{0}$ & $\stackrel{7}{\circ}$ \\
\hline Sistine & $\begin{array}{l}\dot{\delta} \\
\stackrel{8}{0} \\
\dot{0}\end{array}$ & 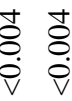 & $\begin{array}{l}\text { ț } \\
\stackrel{0}{0} \\
\dot{v}\end{array}$ & $\begin{array}{l}+ \\
\stackrel{8}{0} \\
\stackrel{0}{V}\end{array}$ & $\begin{array}{l}\text { d } \\
\stackrel{8}{0} \\
\dot{v}\end{array}$ \\
\hline
\end{tabular}

Notes :

1. A(100\% naupli Artemia $), \mathrm{B}(75 \%$ naupli Artemia $+25 \%$ Phronima $)$, C(50\% naupli 
Artemia+50\% Phronima), D(25\% nauplii Artemia $+75 \%$ Phronima $)$ dan E(100\% Phronima);

2. The value of amino acid in the juvenile body is in A and $\mathrm{E}$ treatments were obtained from the result of analysis in Laboratorium;

3. The values of amino acid in B, C, and D treatments were obtained from calculation.

Amino acid analysis produced, ten essential amino acid content found from the body of juvenile seahorse i.e., arginine, lysine, leucine, isoleucine, phenylalanine, valine, methionine, histidine, threonine, and tryptophan (Table 2). The results of the amino acid analysis showed that several types of essential amino acids were deficient in the seahorse juvenile requirements. The number of essential amino acids arginine and phenylalanine in all treatments $\mathrm{A}, \mathrm{B}, \mathrm{C}, \mathrm{D}$, and $\mathrm{E}$ were known deficient in juvenile requirements. $C$ treatment deficient in threonine. $\mathrm{D}$ treatment was deficient in histidine, threonine, valine, lysine, and tryptophan

In treatment $\mathrm{E}$, the total overall essential amino acid contained deficient in juvenile needs.

\section{Survival rate}

Table 3. The mean of survival rate (\%) of sea horses juveniles Hippocampus barbouri

\begin{tabular}{ll}
\hline Treatments & Survival rate (\%) \\
\hline A. $100 \%$ Artemia naupli & $80.00 \pm 10.00^{\mathrm{ab}}$ \\
B. $75 \%$ Artemia naupli $+25 \%$ & $90.00 \pm 17.32^{\mathrm{ab}}$ \\
Phronima sp. & \\
C. 50\% Artemia naupli $+50 \%$ & $96.67 \pm 5.77^{\mathrm{b}}$ \\
Phronima sp. & \\
D. 25\% Artemia naupli $+75 \%$ & $96.67 \pm 5.77^{\mathrm{b}}$ \\
Phronima sp. & \\
E. 100\% Phronima sp. & $63.33 \pm 15.27^{\mathrm{a}}$ \\
\hline
\end{tabular}

Notes: Different letters indicated a significant difference $(\mathrm{P}<0.05)$ of survival rate of juveniles

Substitution of Artemia naupli with Phronima sp. up to $75 \%$ in treatment $\mathrm{D}$ showed a survival rate that was not different from giving 100\% Artemia naupli in treatment A (Table 3). The resulting synthesis in treatment D is $96.67 \pm 5.77 \%$ while in treatment $\mathrm{A}$ is $80.00 \pm 10.00 \%$. However, the substitution of naupli Artemia with Phronima up to $100 \%$ in treatment $\mathrm{E}$ has not been given to the maintenance of seaweed juveniles $\mathrm{H}$. barbouri, which is characterized by the low survival value produced.

The survival of juveniles is influenced by several important factors, one of which is the adequacy of feed nutrients provided during maintenance. Adequacy of juvenile nutrition was analyzed based on proximate analysis and amino acid. The nutritional content of the proximate analysis of the substitution of Artemia and Phronima nauplii in treatment $\mathrm{B}, \mathrm{C}$, and $\mathrm{D}$ is sufficient for the number of juvenile needs, especially in the protein and fat content. The protein and fat content in treatment B was $55.38 \%$ and $17.12 \%$; treatment $\mathrm{C} 49.30 \%$ and $12.69 \%$ and treatment $\mathrm{D} 43.21 \%$ and $8.25 \%$. Juvenile protein and fat requirements are known to range from $40-60 \%$ and $10-20 \%$ respectively (Morais et al., 2001; Watanabe et al., 2001; Skalli et al., 2004 In Woods, 2007). The initial stage of juvenile growth is known to require high protein content (Nenciu et al., 2015; Novelli et al., 2016). The availability of protein and fat in the feed must be at the optimum level because it will affect the work system of the body's metabolism of larvae or juveniles. The protein and fat content is the primary fuel source that determines the quality of the juvenile's ability to survive (Blanco et al., 2011).

The results of the amino acid substitution analysis of Artemia naupli with Phronima in treatments A, $\mathrm{B}$, and $\mathrm{C}$ was sufficient from the average number

of essential amino acids needed for the survival of juveniles. The quality of the protein content of a feed can be seen from the adequacy of essential amino acids in the body's juvenile needs. The existence of amino acids provides different functions for the growth and development of an organism. Amino acids are important basic ingredients during the process of larval growth (Ronnestad et al., 2003). Essential amino acids that are known to play an important role in increasing larval growth and development, namely in histidine, valine, and lysine (Buwono, 2000; Li et al., 2008).

Winarno (2008) explains that amino acids needed by fish must be fulfilled from the feed, especially for amino acids that cannot be synthesized (essential) by the body. Amino acids are the main constituent components of proteins and are divided into two groups, namely essential and nonessential amino acids. Essential amino acids cannot be produced in the body so they often have to be added in the form of food, while nonessential amino acids can be produced in the body (Sitompul, 2004). Essential amino acids are an important source of energy sources to ensure adequate protein content of feed during the growth period (Ronnestad et al., 2003). According to Wijaya (2003), amino acids are needed by the body as an energy source and can function as a source of material for protein synthesis which is very much needed by larvae or juveniles during the organ formation phase.

The low survival rate of substitution of Artemia naupli with Phronima up to $100 \%$ treatment E is thought to be due to the low protein and fat content of the number of juvenile requirements, as well as the amino acid content. Also, the total energy 
produced by treatment $\mathrm{E}$ is low from other treatments (A, B, C, and D). The total energy in treatment A $579.27 \mathrm{kcal} / \mathrm{g}$; treatment B $497.32 \%$; treatment C $415.36 \%$ while treatment E $251.45 \%$. Foods with low energy content can cause fish to use some protein as an energy source for metabolism so that the protein portion for growth is reduced (Pramono et al., 2007). Besides that, the high crude fiber content in treatment $\mathrm{E}$ also causes low growth and survival in the maintenance of seahorse juveniles belonging to carnivorous species. According to Afrianto \& Liviawati (2005), the ability to digest carnivorous fish against crude fiber is relatively low compared to fat and protein. The higher the crude fiber, the higher the feed is difficult to digest (Satyani, 2003) so that the growth and survival of the juvenile become low.

During maintenance of juveniles, the environmental conditions of maintenance media are at the optimum tolerance and growth limits for seaweed H. barbouri juveniles. Temperature 28-30 (Lin et al.., 2009; Abidin et al., 2008), pH 6-7 (Abidin et al., 2008; Syafiuddin, 2008), salinity 30-31 ppm (Abidin et al., 2008), DO 4 , 2-6 mg/L and ammonia $<0.01 \mathrm{mg} / \mathrm{L}$ (Abidin et al., 2008).

\section{CONCLUSION}

Based on the analysis of the quality of seaweed juwana H. barbouri substitution of Artemia naupli with Phronima sp. up to $75 \%$ in treatment D gives a survival value that is not different from giving $100 \%$ Artemia naupli in treatment A. Therefore, the use of Phronima sp. as an alternative feed for the maintenance of seahorse juveniles can be given at a substitution rate of up to $75 \%$.

\section{ACKNOWLEDGMENT}

Thanks to the Faculty of Marine Science and Fisheries Hasanuddin University for the juveline seahorse rearing facilities.

\section{REFERENCES}

Abidin, Z., Fahirus, W., \& Gebbie, E. (2008). Studi Tingkah Laku Pemijahan, Kelahiran \& Pertumbuhan Kuda Laut H. kuda pada Pemeliharaan Sistem Indoor. BBPBL Lampung. 1-12 hal.

Afrianto, E \& Liviawati, E. (2005). Pakan Ikan Kanisius. Yogyakarta. 141 hal.

Blanco, A., Quintas, P., \& Planas, M. (2011). Enhancement in The Rearing of The Seahorse Hippocampus Guttulatus by Feeding on Copepods. International Zoo and Aquarium Symposium-The Husbandry.
Management and Conservation of Syngnathids. Chicago. Illinois (USA).

Buwono, I. B. (2000). Kebutuhan Asam Amino Esensial dalam Ransum Ikan. Kanisius. Yogyakarta

Fattah, M.H. \& Senong, M. (2008). Uji Pendahuluan Kultur Phronima sp. (Phronima sp. sp.) Laboratorium Lapang Akuakultur. Fakultas Perikanan \& Ilmu Kelautan, Universitas Muslim Indonesia (UMI), Makassar.

Fattah, M.H., Senong, M., Asbar \& Rahbiah, B.S. (2014). Production of Endemic Microcrustacean Phronima sp. (Phronima sp. sp) to Subtitute Artemia salina in Tiger Prawn Cultivation. Aquaculter Research and Development. Vol 5.

Handajani, H \& Widodo, W. (2010). Nutrisi Ikan. UMM Press. Malang. 271 hal.

Koldewey, H.J. \& Martin-Smith, K.M., 2010. A Global Review of Seahorse Aquaculture. Aquaculture Journal 302, 131-152. Li, P., Kangsen, M., Jesse, T., \& Guoyao, W. (2008). New Developments in Fish Amino Acid Nutrition: Towards Functional and Environmentally Oriented Aquafeeds. Amino Acids. doi : 10.1007/s00726-0080171-1.

Li, P., Kangsen, M., Jesse, T., \& Guoyao, W. 2008. New Developments in Fish Amino Acid Nutrition: Towards Functional and Environmentally Oriented Aquafeeds. Amino Acids. doi : 10.1007/s00726-0080171-1.

Lin, Q., Zhang, D., \& Lin, J. (2009). Effects of Light intensity, Stocking Density, Feeding Frequency, and Salinity on The Growth of Sub-Adult Seahorses Hippocampus erectus Perry, 1810. Aquaculture 292, 111-116.

Mulyadi, B. 2004. Pengaruh Padat Penebaran terhadap Sintasan \& Pertumbuhan Juwana Kuda Laut (Hippocampus barbouri). Skripsi. Fakultas Ilmu Kelautan Perikanan. Universitas Hasanuddin. Makassar.

Nenciu, M.I et al. (2015). Effects of Different Live Feed Diets Applied to the Long-Snouted Seahorse (Hippocampus guttulatus Cuvier, 1829). Turkish Journal of Fisheries and Aquatic Sciences 15: 401-410.

Novelli, B et al. (2016). Digestive Biochemistry as an Indicator of The Nutritional Status During Early Development of The Long Snouted Seahorse (Hippocampus reidi). 
Aquaculture

Journal

Payne, M.F., \& Rippingale, R.J. (2000). Rearing West Australian seahorse, Hippocampus subelongatus, Juveniles on Copepod Nauplii and Enriched Artemia. Aquaculture 188, 353-361.

Pramono, T.B., Dyahruri, S \& Soedibya, P.H.T. (2007). Optimasi Pakan dengan Level Protein dan Energi Protein untuk Pertumbuhan Calon Induk Ikan Senggaringan (Mystus Nigriceps). Jurnal Optimasi Pakan dengan Level Protein dan Energi Protein, Vol. 15. No.2.

Ronnestad et al. (2003). The Supply of Amino Acids During Early Feeding Stages of Marine Fish Larvae: A Review of Recent Findings. Aquaculture 227 (2003) 147-164.

Rosa, I.L., Oliveira, T.P., Osório, F.M., Moraes, L.E., Castro, A.L., Barros, G.M \& Alves, R.R. 2011. Fisheries and Trade of Seahorses In Brazil: Historical Perspective, Current Trends, and Future Directions. Biod. Cons. 20, 1951-1971. Santoso, B. (2014). Analisis Jenis Makanan Kuda Laut Hippocampus barbouri, (Jor\& \& Richardson, 1908) Pada Daerah Padang Lamun di Kepulauan Tanakeke, Takalar, Sulawesi Selatan. Skripsi. Fakultas Ilmu Kelautan \& Perikanan. Universitas Hasanuddin. 10.1016/j.aquaculture.2016.06.037.

Satyani, D. (2003). Pengaruh Umur Ikan Induk ikan Cupang (Betta splenden Regan) \& Jenis Pakan Terhadap Fekunditas \& Produksi Larvanya. Jurnal Penelitian Perikanan Indonesia. 9(4): 13-18.

Sitompul, S. (2004). Analisis Asam Amino dalam Tepung Ikan \& Bungkil Kedelai. Buletin Teknik Pertanian 9(1):33-37.

Syafiuddin. (2004). Pembenihan \& Penangkaran sebagai Alternatif Pelestarian Populasi Kuda Laut (Hippocampus spp.) di Alam. Makalah Falsafah Sains. IPB, Bogor.

Wijaya, R. (2003). Pengaruh Penambahan Multi Asam Amino Esensial Dalam Media Kultur Terhadap Tingkat Kelangsungan Hidup \& Pertumbuhan Larva Ikan Nilem (Osteochilus hasselti C.V). Tesis. Program Pasca Sarjana, Institut Pertanian Bogor, Bogor.

Winarno, F.G. 2008. Kimia Pangan \& Gizi. Bogor. M-Brioo Press.

Woods, C.M.C. (2007). Aquaculture of The Big_bellied Seahorses Hippocampus Abdominalis Lesson 1827 (Teleostei: Syngnathidae). Thesis. Philosophy in Biological Sciences. Victoria University of Wellington. 